\title{
Integrated Water and Weed Management of Sugar Beet Crop by Using Different Mulching in New Reclaimed Areas
}

\author{
Mohamed A. M. Moursy ${ }^{1}$, Mohamed S. El-Kady ${ }^{2}$, Lamy M. M. Hamed ${ }^{3 *}$, Talat A. Ibrahim¹, \\ and Eman. I. R. Emara ${ }^{4}$
}

\begin{abstract}
Soil and water agro-management techniques play a critical role in grown crops to increase productivity. Mulching is one of the good agriculture practices methods to conserve soil moisture, control weeds and improve soil physical properties. Two field experiments were implemented at Wadi El-Natron Research Station, Water Management Research Institute, National Water Research Center, Egypt, during 2017/2018 and 2018/2019 winter seasons to evaluate the effect of four mulching types, No Mulch (NM, Control), Rice Straw Mulch (RSM), White Polyethylene Film Mulch (WPFM) and Black Polyethylene Film Mulch (BPFM) of sugar beet (Beta vulgaris $L$. cv, Zwanpoly) yield and quality as well as water use efficiency for root (WUE $\left.E_{\text {root}}\right)$ and sugar (WUE $E_{\text {sugar }}$ ) in sandy soil. Significant differences among mulching types were observed. The results indicated that, both BPFM and WPFM recorded the highest sucrose values (21.14 and $19.77 \%)$, purity (85.88 and $82.01 \%)$, extractable sugar (19.49 and $17.68 \%)$, root yield (58.70 and 53.92 ton ha ha $\left.^{-1}\right)$ and sugar yield (11.44 and 9.53 ton $\left.\mathrm{ha}^{-1}\right)$ in the $1^{\text {st }}$ and $2^{\text {nd }}$ season, respectively. On the contrary, NM recorded the highest impurities percentage and low weed control efficiency. Average of WUEroot (6.08, 7.36, 9.78 and 9.97 $\left.\mathrm{kg} \mathrm{m}^{-3}\right)$ and WUE sugar $\left(0.89,1.16,1.73\right.$ and $\left.1.94 \mathrm{~kg} \mathrm{~m}^{-3}\right)$ resulted from NM, RSM, WPFM, and BPFM, respectively, as an average in two seasons. Weed control efficiency values were $(40.9,30.45,5.2$ and zero\%) for BPFM, WPFM, RSM, and NM, respectively and that helped in maintaining higher moisture content in the crop root zone.
\end{abstract}

Keywords: Mulching, Sugar beet, WUE, Polyethylene.

\section{INTRODUCTION}

Mulching is one of the best agronomic practices in conserving soil moisture, prevents weed growth and sequently reduces the application of chemical herbicide and improves soil structure (Patil et al., 2013, Sharma et al., 2017), as well as reduces evaporation and save irrigation water (Yamanaka et al., 2004). In general, areas with a high rich of water or wind erosion, mulch systems

DOI: 10.21608/asejaiqjsae.2021.155560

${ }^{1}$ Water Management Research Institute, National Water Research Center, 13621/5, Qaliubiya, Egypt

${ }^{2}$ Sugar Crops Research Institute, Agriculture Research Center, Giza, Egypt.

${ }^{3}$ Soil and Water Department, Faculty of Agriculture, Cairo University, 12613, Giza, Egypt

${ }^{4}$ Agronomy Department, Faculty of Agriculture, Cairo University

, 12613, Giza, Egypt

Corresponding Author*:Email:- Lamy.hamed@agr.cu.edu.eg

Phone:- +2 01224091515 / +2 01024759444

Received January20, 2021, Accepted, March 07, 2021 are already well established, it can help to improve soil fertility and reduce nitrogen leaching as well which obtain a high field emergence and a good plant development (Teasdale, 1996, Petersen and Rover, 2004), also controlling weeds completion (DeBaets et al., 2011, Sturm et al., 2016).

There are various types of mulch such as surface mulching, polyethylene mulching, pebble mulching, dust mulching live vegetative barriers, straw mulching ...etc. Zhang et al. (2009) and Kanani et al. (2016) reported that mulching increased the biological yield and water use efficiency compared to no mulch treatment, fresh yield increased by 76 and $49 \%$ as well as water use efficiency that increased by 143 and $100 \%$ under rice straw mulch treatment compared to control and gravel mulch treatments, respectively. Also, Dregseth et al. (2003) reported that oat mulch increased sugar beet root yield by $6.8 \%$ compared with No-mulch. At the same trend, Afshar et al. (2018) mentioned that growing sugar beet with mulch can be successfully implemented without or minimal negative impact on sugar beet productivity with less accumulation of impurities in beetroots. Sodium, potassium and amino $\mathrm{N}$ content were significantly influenced by mulch treatment, likewise, impurities reduce sucrose loss to molasses (SLM) which indicated that more sucrose can be produced during the extraction process and increase the sugar production in final. Malik et al. (2018b) found that black polyethylene film mulch was better compared to straw mulch. BPFM and the straw mulch produced 11.96 to $19.45 \%$ higher root yield, 14.33 to $22.68 \%$ higher sugar yield, 17.07 to $30.68 \%$ higher root crop WUE and WUE for sugar increased by 19.57 to $33.53 \%$ compared to no mulch treatment. On the other hand, Yonts et al. (2002) mentioned that mulch did not affect sugar beet root and sucrose yield, however Yi et al. (2007) and Li et al. (2012) noticed the positive response of mulch application as straw and plastic sheet mulch significantly decreased water loss by evaporation. Straw 
mulching increased plant height, dry matter weight, seed index and yield of maize, however, plastic sheet mulch was more effective in conserving soil water than straw mulch. Tunio et al. (2007) and Salman et al. (2015) tested different mulches, control (no mulch), wheat straw, sugarcane trash and plastic sheet mulch on sunflower crop. They showed that germination and yield differed significantly among mulching treatments compared to control. The plastic sheet recorded the highest yield and efficiently control weeds. Covering soybean row by 3 tons of wheat straw per hectare can improve emergence and yield by lowering the maximum soil temperature and conserving soil moisture (Singh and Jolly, 2008).

The effect of mulch practice on sugar beet yield and water use efficiency in newly reclaimed areas has not been widely investigated, therefore, the target of this investigation was to study the effect of different mulching types on yield, quality and water use efficiency of sugar beet under drip irrigation in new reclaimed soil.

\section{MATERIALS AND METHODS}

\section{Experimental design}

Two field experiments were conducted at Wadi ElNatroon Station of Water Management Research Institute, El-Behera Governorate, Egypt. The experiments implemented during $15^{\text {th }}$ and $16^{\text {th }}$ of September 2017/2018 and 2018/2019 seasons, respectively, study the effect of four mulching types on quality and yield of sugar beet (Beta vulgaris L. $c v$, Zwanpoly) as well as water use efficiency in sandy soil under a drip irrigation system. The application efficiency was calculated by using the equation according to $\mathrm{Wu}$ and Gitlin (1973):

$$
E_{a}=\left(q_{\min } / q_{\text {avg }}\right) \times 100
$$

where: $q_{\min }$ is the Minimum emitter flow rate and $q_{\text {avg }}$ Mean emitter flow rate $\left(1 \mathrm{~h}^{-1}\right)$ " and found that the application efficiency of the irrigation network was $88 \%$. This value was calculated before starting the experiment. Soil Physical and chemical analyses of the experimental site are presented in Table (1 and 2). The experimental design arrangement was randomized complete blocks with four replicates. Irrigation system components consisted of water source from well, control head, pump, filtration unit, pressure regulator, pressure gauges, flow meter, and control valves. Mainline of $160 \mathrm{~mm}$ diameter PVC pipe was connected with sub mainline $110 \mathrm{~mm}$ diameter and manifold lines of 75 and $63 \mathrm{~mm}$ diameters. Lateral emitters were made frorm polyethylene (PE) with $16 \mathrm{~mm}$ diameter, $25 \mathrm{~m}$ length and $30 \mathrm{~cm}$ between emitters. Emitters discharge was $3.8 \mathrm{l} \mathrm{h}^{-1}$ at 1.2 bar operating pressure. Plot area dimensions were 15 length $\times 3.5 \mathrm{~m}$ width and was consisting of 5 rows with $1 \mathrm{~m}$ distance between each plot.

Table 1. Soil physical properties of experimental Site

\begin{tabular}{|c|c|c|c|c|c|c|c|c|}
\hline \multirow[b]{2}{*}{ Soil layer $(\mathbf{c m})$} & \multicolumn{3}{|c|}{ Particle size distribution $\%$} & \multirow{2}{*}{$\begin{array}{l}\text { Texture } \\
\text { class }\end{array}$} & \multirow{2}{*}{$\begin{array}{c}\text { Bd } \\
\left(\mathrm{gm} \mathrm{cm}^{-3}\right)\end{array}$} & \multicolumn{3}{|c|}{ Moisture content by weight $(\%)$} \\
\hline & Sand & Silt & Clay & & & F. C & W.P & A.W \\
\hline $0-20$ & 94.5 & 3.5 & 2.0 & & 1.65 & 8.03 & 3.33 & 4.7 \\
\hline $20-40$ & 95.0 & 3.3 & 1.7 & Sandy & 1.56 & 9.13 & 3.14 & 5.99 \\
\hline $40-60$ & 95.7 & 3.0 & 1.3 & & 1.44 & 10.07 & 2.99 & 7.08 \\
\hline
\end{tabular}

Table 2. Soil chemical properties of experimental Site

\begin{tabular}{|c|c|c|c|c|c|c|c|c|c|c|c|}
\hline \multirow[t]{2}{*}{$\begin{array}{c}\text { Soil layer } \\
\text { Cm }\end{array}$} & \multirow[t]{2}{*}{ SAR } & \multirow[t]{2}{*}{ PH } & \multirow{2}{*}{ 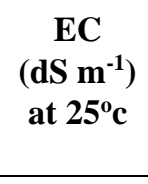 } & \multicolumn{4}{|c|}{$\begin{array}{l}\text { Soluble anions } \\
\quad\left(\text { meq }^{\mathbf{l}^{-1}}\right)\end{array}$} & \multicolumn{4}{|c|}{$\begin{array}{l}\text { Soluble cations } \\
\quad\left(\text { meq l}^{-1}\right)\end{array}$} \\
\hline & & & & $\mathrm{CO}_{3}^{--}$ & $\mathrm{HCO}_{3}{ }^{-}$ & $\mathrm{Cl}^{-}$ & $\mathrm{SO}_{4}^{--}$ & $\mathbf{C a}^{++}$ & $\mathbf{M g}^{++}$ & $\mathrm{Na}^{+}$ & $\mathbf{K}^{+}$ \\
\hline $0-20$ & 1.66 & 8.23 & 1.46 & 0.1 & 0.93 & 1.98 & 9.61 & 6.23 & 2.24 & 3.44 & 0.51 \\
\hline $20-40$ & 1.74 & 8.11 & 1.56 & 0.1 & 1.15 & 2.05 & 9.85 & 6.45 & 2.26 & 3.76 & 0.58 \\
\hline $40-60$ & 1.84 & 7.97 & 1.63 & 0.1 & 1.33 & 2.11 & 10.16 & 6.65 & 2.29 & 3.91 & 0.65 \\
\hline
\end{tabular}


Table 3. Chemical Analysis of Irrigation Water

\begin{tabular}{|c|c|c|c|c|c|c|c|c|c|c|c|c|c|}
\hline \multirow[t]{2}{*}{ PH } & \multirow{2}{*}{ 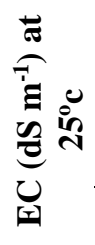 } & \multicolumn{4}{|c|}{$\begin{array}{l}\text { Soluble anions } \\
\quad\left(\text { meq }^{-1}\right)\end{array}$} & \multicolumn{4}{|c|}{$\begin{array}{l}\text { Soluble cations } \\
\quad\left(\text { meq }^{-1}\right)\end{array}$} & \multirow[t]{2}{*}{ SAR } & \multirow[t]{2}{*}{ RSC } & \multirow[t]{2}{*}{ ESP } & \multirow[t]{2}{*}{ Uે } \\
\hline & & $\mathrm{CO}_{3}^{--}$ & $\mathrm{HCO}_{3}^{-}$ & $\mathrm{Cl}^{-}$ & $\mathrm{SO}_{4}^{--}$ & $\mathbf{C a}^{++}$ & $\mathbf{M g}^{++}$ & $\mathrm{Na}^{+}$ & $\mathbf{K}^{+}$ & & & & \\
\hline 7.14 & 1.18 & 0.1 & 4.7 & 10.6 & 8.15 & 1.8 & 2.8 & 18.4 & 0.55 & 12.1 & 0.2 & 78.1 & 9.8 \\
\hline
\end{tabular}

\section{Studied treatments}

In this study, we were focused on four mulch treatments: (1) Control, No Mulch (NM), (2) Rice Straw Mulch (RSM): 8.5 ton.ha $^{-1}$ (5 cm height), (3) White Polyethylene Film Mulch (WPFM) and (4) Black Polyethylene Film Mulch (BPFM). WPFM and BPFM consisted of transparent white and black coloured polyethylene strip sheets of $15 \mathrm{~m}$ length with $0.75 \mathrm{~m}$ width laid down on the soil surface up the lateral line. Holes of $0.05 \mathrm{~m}$ in diameter were created over each emitter in the center of the sheet for planting. Seeds were placed in hills $30 \mathrm{~cm}$ apart within row. Seedlings were thinned at 4-6 leaf stage (after once month from sowing) to ensure one plant per hill. Other agricultural practices were made as described by the Egyptian Ministry of Agriculture. The total amount of irrigation water was 6369, 6145, 5509 and 5888(calculated or recommended)) $\mathrm{m}^{3} \cdot \mathrm{ha}^{-1}$ for NM, RSM, WPFM, and BPFM, respectively. Chemical analysis of irrigation water presented in Table (3). Harvest was done after 180 days from sowing.

\section{Studied traits}

\section{Quality traits}

At harvest, samples of ten sugar beet plants were taken randomly from the central area of each plot to determine the following juice quality traits: Total Soluble Solids (T.S.S)\% was determined by using a digital refractometer, model PRI (ATAGO). Sucrose was determined by using saccharometer on lead acetate extract of fresh macerated roots (Carruthers and Oldfield, 1960). Purity \% according to Carruthers et al. (1962) as follow: Purity \% = (Sucrose / T.S.S)* 100. Impurities component i.e. K, $\mathrm{Na}$, and amino $\mathrm{N}$ (milleq/100gm beet) according to the method as described by A.O.A.C (1980). Impurities percentage was determined according to Carruthers and Oldfield (1960) as follows

$$
\begin{gathered}
\text { Impurities } \%=((K+N a) * 0.0343) \\
+(\text { Amino } N * 0.094)+0.29
\end{gathered}
$$

Extractable sugar percentage that calculated according to Renfield et al. (1993) as follows:

$$
\begin{gathered}
\text { Extractable Sugar }=\text { Sucrose \% - 0.029 - } \\
(0.343(N a+K)-0.094(\text { amino-N) }
\end{gathered}
$$

\section{Yield}

At harvest, plants of three middle rows from each plot were uprooted and toped to determine the following parameters: root and Sugar yield (ton ha ${ }^{-1}$ ).

$$
\begin{aligned}
& \text { Sugar Yield }\left(\text { ton } \cdot \mathrm{ha}^{-1}\right)=\text { Root Yield } \\
& \left(\text { ton. } h a^{-1}\right) * \text { Extractable Sugar } \%
\end{aligned}
$$

\section{Weed Parameters Weed population count}

The total number of weeds present in $1.0 \mathrm{~m}^{2}$ area in a permanently marked sampling area was counted at 30 , $60,90,120$ DAT in each treatment.

Dry weight of weeds $\left(\mathrm{g} . \mathrm{m}^{-2}\right)$ was recorded at periodical intervals i.e., 30, 60, 90, 120 DAT in each treatment. The weeds were uprooted from the $1 \mathrm{~m}^{2}$ area selected randomly each time and were oven-dried to a constant weight at $65^{\circ} \mathrm{C}$ and the oven-dry weight of weeds was recorded. The dry weight of weeds was expressed as $\mathrm{g}$ per $1.0 \mathrm{~m}^{2}$

Weed control efficiency (\%) (WCE) denotes the magnitude of weed reduction due to weed control treatment. It was worked out by using the formula suggested by Mani et al. (1973) and expressed in percentage. 
WCE $(96)=\frac{\text { Dryweight of weed in unweeded control }- \text { Dryweight of treatment plot }}{\text { Dry weight of weed inumweeded contral }} \times 100$

\section{Amount of applied water}

The depth of irrigation was calculated according to the equation given by Israelsen and Hansen (1962).

$$
D_{\text {aiw }}=\frac{F \cdot C \cdot-\theta 1}{100} X B d X d
$$

Where:

Daiw : Depth of irrigation water applied. (mm)

F.C. : Soil moisture content at field capacity by weight. (\%)

Ө1 : Soil moisture content before irrigation by weight. (\%)

$\mathrm{Bd}:$ Bulk density. $\left(\mathrm{gm} \mathrm{cm}^{-3}\right)$

d : Soil depth. (mm)

\section{Water use efficiency}

Water use efficiency for root and sugar yield was measured according to Jensen (1983).

$$
\begin{aligned}
& \text { WUE } E_{\text {root }}\left(\mathrm{kg}_{\mathrm{g}} \mathrm{m}^{-\mathrm{a}}\right)= \\
& \frac{\text { Root Yield }\left(\mathrm{kg}_{\mathrm{*}} \mathrm{ha}^{-1}\right)}{\text { Actual Applied Water }\left(\mathrm{m}^{2} \cdot \mathrm{ha}^{-1}\right)} \\
& W U E_{\text {Sugar }}\left(\mathrm{kg} \cdot \mathrm{m}^{-\mathrm{d}}\right)= \\
& \text { Sugar Yield }\left(\mathrm{kg}_{\mathrm{s}} \mathrm{ha}^{-1}\right) \\
& \text { Actual Applied Water }\left(m^{2}{ }^{2} a^{-1}\right)
\end{aligned}
$$

\section{Economic evaluation}

Costs, including the costs of the network, irrigation, labours, mulch material, soil preparation, fertilizers, weed control, and pesticides.

Gross Return, including the prices in Egyptian Pound (LE) which paid for harvesting of sugar beet yield (ton $\mathrm{ha}^{-1}$ ).

Net Return $=$ Gross Return - Costs .

The average prices were taken from the local market prices. The economic evaluation was done using the methods described by CIMMYT (1988).

\section{Statistical analysis:}

Quality traits, beet yields and water use efficiency were statistically analyzed according to Snedecor and Cochran (1976) using analysis of variance technique of computer software package (Mstat-c, 1989). Comparison among treatment means was done using least significant differences (L.S.D) at 5\% level of probability according to Steel and Torrie (1980).

\section{RESULTS AND DISCUSSION}

\section{Mulching effects on juice quality}

Data presented in Table (4) shows that the four mulching treatments, i.e. NM, RSM, WPFM, and BPFM, significantly affected the quality traits in terms of sucrose, purity, potassium, sodium, amino $\mathrm{N}$ and impurities percentage in both seasons, except amino $\mathrm{N}$ and impurities in the second season. BPFM recorded the highest sucrose (21.10 and $21.18 \%$ ) and purity (85.77 and $85.98 \%$ ) in the first and second season along with the lowest amine- $\mathrm{N}$ impurities percentage $(1.65 \%$ and 0.76 ) in the $1^{\text {st }}$ season, respectively, followed by WPFM, RSM, and NM in descending order. Using BPFM recorded a significant increase in sucrose by $6.96,14.61$ and $19.30 \%$ and in purity percentage by $4.71,8.28$ and $10.41 \%$, on the other hand, impurities percentage reduced by $24.50,38.49$ and $46.38 \%$ compared to WPFM, RSM, and NM, respectively. These results are in harmony with those obtained by Helaly et al. (2017) and Malik et al. (2018a) whom they reported that black or white film mulch and straw mulch increased sugar content of sugar beet by 2.35 and $3.78 \%$ as well as Physalis Pubescens by 8.10 and $38.20 \%$, respectively compared to no mulch. In general, different kinds and color mulches increased sugar content followed by straw mulch (Parmar et al., 2013). Positive effect of mulching on juice quality might be due to the promotion effect in plant growth, metabolic process and translocation of carbohydrates from tops to roots (Helaly et al., 2017).

\section{Mulching effects on sugar beet yield}

Beet yields differed significantly among mulch treatments in both seasons as well as extractable sugar percentage (Table 5). Consequently, of the positive 
effect of mulching on sugar beet growth and quality, the highest root yield (58.51 and 58.90 ton $\mathrm{ha}^{-1}$ ), extractable sugar (19.45 and $19.52 \%)$ and sugar yield (11.38 and 11.50 ton $\mathrm{ha}^{-1}$ ) in the first and second season, respectively, resulted from BPFM followed by WPFM, RSM and NM. An increase recorded for using each mulching types i.e. root yield increased by $16.8,39.2$ and $51.6 \%$, extractable sugar 7.7, 20.5 and $32.8 \%$, sugar yield increased by $25.8,67.7$ and $101.3 \%$ as well for RSM, WPFM and BPFM treatment compared to no mulch (NM) (Fig. 1).

Mulching can enhance the available soil moisture condition by collecting micro efficient or ineffective precipitation, reducing soil evaporation and restraining runoff (Chen et al., 2019), especially, polyethylene mulch that increase soil temperature and microclimate modification (Sarkar and Singh, 2007, Malik et al., 2018b). So sugar beet plants grew quickly and consequently, the photosynthetic rate and production of dry matter increased which significantly increased root yield compared with no mulch. As sucrose content increased and impurities decreased, extractable sugar percentage increased. This increase in root yield and extractable sugar \% increased sugar yield by using different mulching types. These results are in agreement with those obtained by Artyszak et al. (2014) who mentioned that grew sugar beet crop under straw mulch treatment increased root yield by $25 \%$ and sugar yield by $11.3 \%$ compared to no mulch. Malik et al. (2018a) found that the highest root and sugar yield produced by black film mulch treatment. In contrast, Tegen et al. (2016) reported that straw mulch treatment enhances yield compared to BPFM.

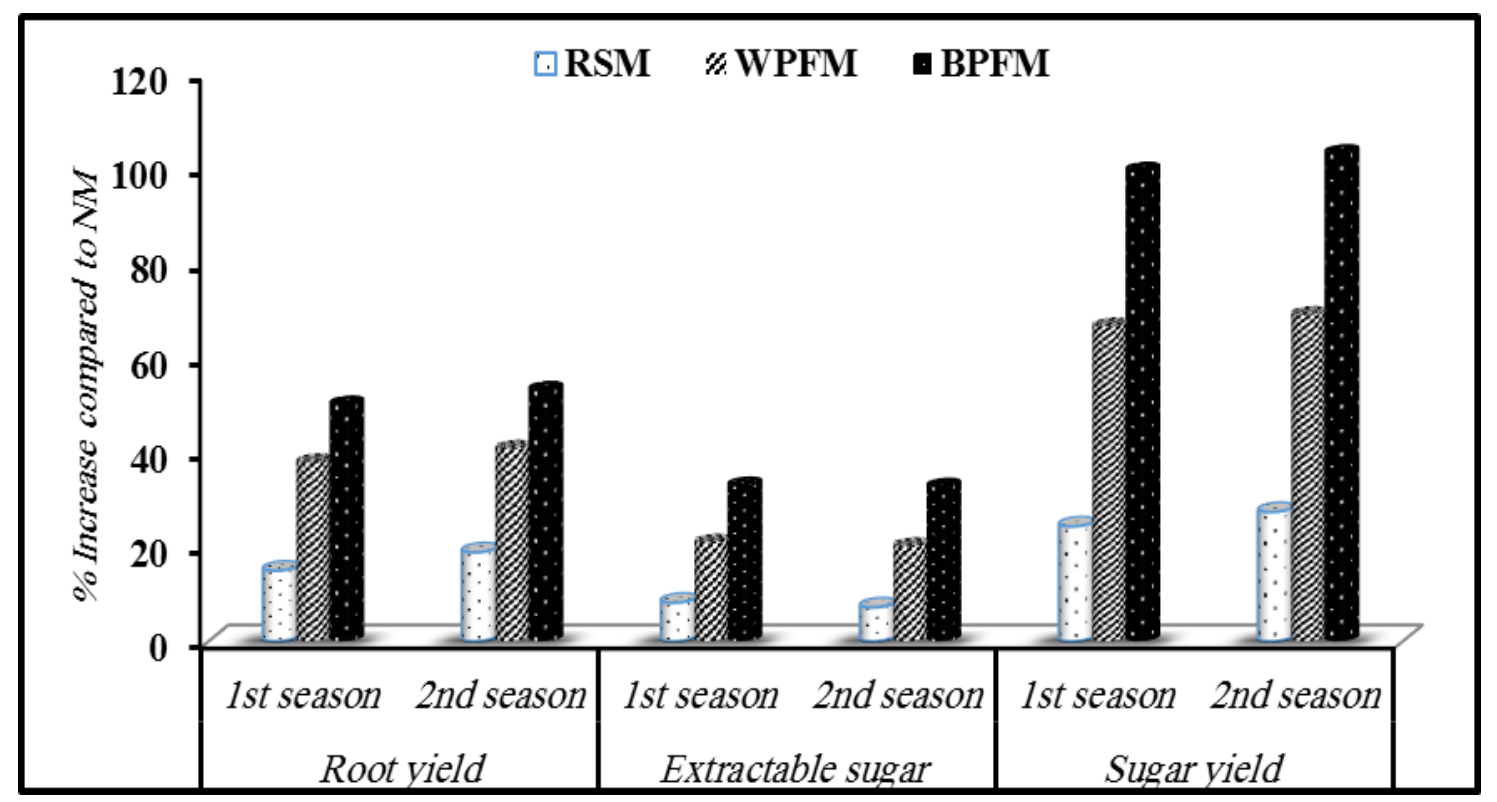

Fig. 1. Percent increase in root yield, extractable sugar and sugar yield of rice straw mulch (RSM), white polyethylene film mulch (WPFM) and black polyethylene film mulch (BPFM) compared to control, no mulch (NM) in 2018-19 and 2019-20 seasons 
Table 4. Quality traits of sugar beet roots as affected by different mulching type in 2018/2019 and $2019 / 2020$ seasons

\begin{tabular}{|c|c|c|c|c|c|c|c|c|c|c|c|c|}
\hline \multirow{2}{*}{ Treatment } & \multicolumn{2}{|c|}{ sucrose \% } & \multicolumn{2}{|c|}{ purity $\%$} & \multicolumn{2}{|c|}{$\mathbf{K}$} & \multicolumn{2}{|c|}{ Amino-N } & \multicolumn{2}{|c|}{$\mathbf{N a}$} & \multicolumn{2}{|c|}{ Impurities \% } \\
\hline & $1^{\text {st }}$ season & $2^{\text {nd }}$ season & $1^{\text {st }}$ season & $2^{\text {nd }}$ season & $1^{\text {st }}$ season & $2^{\text {nd }}$ season & $1^{\text {st }}$ season & $2^{\text {nd }}$ season & $1^{\text {st }}$ season & $2^{\text {nd }}$ season & $1^{\text {st }}$ season & $2^{\text {nd }}$ season \\
\hline NM & $17.65 \mathrm{~d}$ & $17.79 \mathrm{~d}$ & $77.45 \mathrm{~d}$ & $78.11 \mathrm{~d}$ & $5.57 \mathrm{a}$ & $5.70 \mathrm{a}$ & $1.84 \mathrm{a}$ & $1.86 \mathrm{a}$ & $1.95 \mathrm{a}$ & $1.97 \mathrm{a}$ & $3.01 \mathrm{a}$ & $3.07 \mathrm{a}$ \\
\hline RSM & $18.47 \mathrm{c}$ & $18.42 \mathrm{c}$ & $79.47 \mathrm{c}$ & $79.14 \mathrm{c}$ & $5.21 \mathrm{~b}$ & $5.21 \mathrm{~b}$ & $1.27 \mathrm{~b}$ & $1.27 \mathrm{a}$ & $1.44 \mathrm{~b}$ & $1.47 \mathrm{~b}$ & $2.65 \mathrm{~b}$ & $2.65 \mathrm{a}$ \\
\hline WPFM & $19.74 b$ & $19.79 \mathrm{~b}$ & $82.13 \mathrm{~b}$ & $81.90 \mathrm{~b}$ & $4.03 \mathrm{c}$ & $4.05 \mathrm{c}$ & $0.99 \mathrm{c}$ & $0.91 \mathrm{a}$ & $0.99 \mathrm{c}$ & $1.00 \mathrm{c}$ & $2.21 \mathrm{c}$ & $2.11 \mathrm{a}$ \\
\hline BPFM & $21.10 \mathrm{a}$ & $21.18 \mathrm{a}$ & $85.77 \mathrm{a}$ & $85.98 \mathrm{a}$ & $3.04 \mathrm{~d}$ & $3.05 \mathrm{~d}$ & $0.76 \mathrm{~d}$ & $0.75 \mathrm{a}$ & $0.62 \mathrm{~d}$ & $0.65 \mathrm{~d}$ & $1.65 \mathrm{~d}$ & $1.61 \mathrm{a}$ \\
\hline L.S.D at $5 \%$ & 0.40 & 0.14 & 1.68 & 0.21 & 0.23 & 0.03 & 0.06 & N.S & 0.06 & 0.03 & 0.09 & N.S \\
\hline
\end{tabular}

Means followed by the same letter are statistically equalled at 5\% level, NM: no mulch (Control), RSM: Rice straw mulch, WPFM: White polyethylene film mulch and BPFM: Black polyethylene film mulch

N.S. Not significant

Table 5. Sugar beet root yield, extractable sugar and sugar yield as affected by different mulching type in 2018/2019 and 2019/2020 season

\begin{tabular}{|c|c|c|c|c|c|c|}
\hline \multirow{2}{*}{ Treatment } & \multicolumn{2}{|c|}{ Root yield (ton ha $a^{\wedge-1}$ ) } & \multicolumn{2}{|c|}{ Extractable sugar \% } & \multicolumn{2}{|c|}{ Sugar yield (ton ha ${ }^{\AA-1}$ ) } \\
\hline & $1^{\text {st }}$ season & $2^{\text {nd }}$ season & $1^{\text {st }}$ season & $2^{\text {nd }}$ season & $1^{\text {st }}$ season & $2^{\text {nd }}$ season \\
\hline NM & $39.00 \mathrm{~d}$ & $38.46 \mathrm{~d}$ & $14.63 \mathrm{~d}$ & $14.72 \mathrm{~d}$ & $5.71 \mathrm{~d}$ & $5.66 \mathrm{~d}$ \\
\hline RSM & $44.81 \mathrm{c}$ & $45.68 \mathrm{c}$ & $15.82 \mathrm{c}$ & $15.77 \mathrm{c}$ & $7.09 \mathrm{c}$ & $7.20 \mathrm{c}$ \\
\hline WPFM & $53.74 \mathrm{~b}$ & $54.10 \mathrm{~b}$ & $17.68 \mathrm{~b}$ & $17.67 \mathrm{~b}$ & $9.50 \mathrm{~b}$ & $9.56 \mathrm{~b}$ \\
\hline BPFM & $58.51 \mathrm{a}$ & $58.90 \mathrm{a}$ & $19.45 \mathrm{a}$ & $19.52 \mathrm{a}$ & $11.38 \mathrm{a}$ & $11.50 \mathrm{a}$ \\
\hline L.S.D at $5 \%$ & 2.09 & 0.39 & 0.34 & 0.12 & 0.39 & 0.08 \\
\hline
\end{tabular}

Means followed by the same letter are statistically equalled at 5\% level, NM: no mulch (Control), RSM: Rice straw mulch, WPFM: White polyethylene film mulch and BPFM: Black polyethylene film mulch 
Mulching effects on Amount of irrigation water applied and water use efficiency.

The amount of irrigation water applied for sugar beet throughout the studed growing seasons under mulching treatments is given in Table (6). The irrigation system plays an important role to save water in the field by using good agricultural practises. Obtained data revealed that the higher amount of irrigation water applied was found under NM, while the lowest was found WPFM. WPFM decreased the amount of irrigation water applied compared with another mulching from 6373, 6147 and 5886 to $5512 \mathrm{~m}^{3} \mathrm{ha}^{-1}$ in the first season and 6368, 6148, 5890 to $5509 \mathrm{~m}^{3} \mathrm{ha}^{-1}$ in the second season compared with NM, RSM and BPFM.

Mulching types significantly increased water use efficiency for both root (WUE $\mathrm{Woot})$ and sugar $\left(\mathrm{WUE}_{\text {sugar }}\right)$ in the two growing seasons (Table 6). RSM increased WUE $_{\text {root }}$ by 19.1 and $23 \%$ and WUE $_{\text {sugar }}$ by 27.8 and $31.5 \%$, WPFM increases WUE $_{\text {root }}$ by 59.3 and $62.6 \%$ and $\mathrm{WUE}_{\text {sugar }}$ by 92.5 and $95.3 \%$ and BPFM recorded the highest WUE root $(62.3$ and $65.6 \%)$ as well as WUE sugar (115.7 and $119.7 \%)$ compared to NM in the $1^{\text {st }}$ and $2^{\text {nd }}$ season, respectively (Fig. 2).

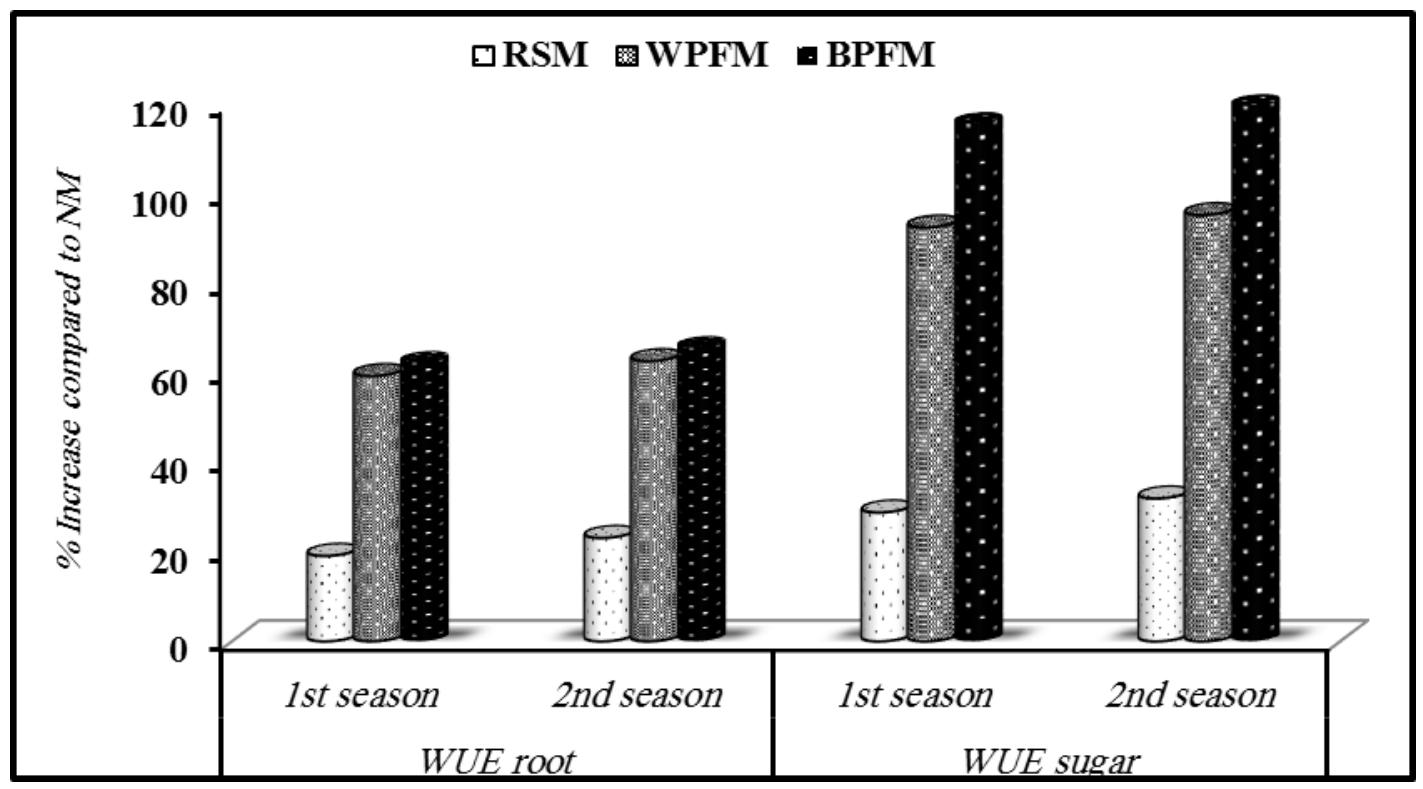

Fig. 2. Percent increase in water use efficiency for root (WUE root) and for sugar (WUE sugar) of rice straw mulch (RSM), white polyethylene film mulch (WPFM) and black polyethylene film mulch (BPFM) compared to control, no mulch (NM) in 2018-19 and 2019-20 season

Table 6. Amount of irrigation water and water use efficiency for root $\left(W_{U} E_{\text {root }}\right)$ and sugar (WUE sugar) as affected by different mulching type in $2018 / 2019$ and $2019 / 2020$ seasons

\begin{tabular}{|c|c|c|c|c|c|c|}
\hline \multirow[t]{2}{*}{ Treatment } & \multicolumn{2}{|c|}{$\begin{array}{l}\text { Amount of irrigation water } \\
\qquad\left(\mathrm{m}^{3} \mathrm{ha}^{-1}\right)\end{array}$} & \multicolumn{2}{|c|}{ WUE root $\left(\mathrm{kg} \mathrm{m}^{-3}\right)$} & \multicolumn{2}{|c|}{ WUE sugar $\left(\mathrm{kg} \mathrm{m}^{-3}\right)$} \\
\hline & $1^{\text {st }}$ season & $2^{\text {nd }}$ season & $1^{\text {st }}$ season & $2^{\text {nd }}$ season & $1^{\text {st }}$ season & $2^{\text {nd }}$ season \\
\hline NM & 6373 & 6368 & $6.12 \mathrm{c}$ & $6.04 \mathrm{~d}$ & $0.90 \mathrm{~d}$ & $0.89 \mathrm{~d}$ \\
\hline RSM & 6147 & 6148 & $7.29 \mathrm{~b}$ & $7.43 \mathrm{c}$ & $1.15 \mathrm{c}$ & $1.17 \mathrm{c}$ \\
\hline WPFM & 5512 & 5509 & $9.75 \mathrm{a}$ & $9.82 \mathrm{~b}$ & $1.72 \mathrm{~b}$ & $1.74 \mathrm{~b}$ \\
\hline BPFM & 5886 & 5890 & $9.94 \mathrm{a}$ & $10.00 \mathrm{a}$ & $1.93 \mathrm{a}$ & $1.95 \mathrm{a}$ \\
\hline L.S.D at $5 \%$ & & & 0.67 & 0.06 & 0.13 & 0.06 \\
\hline
\end{tabular}

Means followed by the same letter are statistically equalled at 5\% probability level, NM: no mulch (Control), RSM: Rice straw mulch, WPFM: White polyethylene film mulch and BPFM: Black polyethylene film mulch. 
Such results match with the recommendation of Malik et al. (2018b) who mentioned that for sustainable and efficient use of the available water resources, fieldscale water-saving strategies must be applied to enhance the water productivity and crop yield, and noticed that using black film and straw mulch saved irrigation water up to $66.53 \%$ compared to no mulch. Gan et al. (2013) noticed that using plastic film mulch has proved effective for increasing crop productivity and WUE in semiarid areas. The relatively low WUE noted for no mulch treatment may be due to the uninterrupted supply of solar radiation that reached the earth surface and thus increased the amount of non- beneficial evaporation and ultimately led to towards lower WUE (Mukherjee et al., 2010, Malik et al., 2018a), whereas the highest WUE under BPFM may be attributed to prevent most of the soil evaporation. In general, mulches improve WUE (Xie et al., 2005).

\section{Mulching effects on Weed Parameters}

Total number of weeds (Table 7) was increased in treatment NM, while decreased by using BPFM. The control treatment (NM) had the highest mean weeds number ( 60.3 broad leaves and 21.7 grasses $\mathrm{m}^{-2}$ ), which was expected as no mulch was applied. In contrast, shredded BPFM had the lowest mean of weeds number (41.3 broad leaves and 16.3 grasses $\mathrm{m}^{-2}$ ), making it the most effective at controlling weeds.

Concerning the effect of type of mulching on weed biomass, obtained result showed that BPFM decreased the value by about $40.1,37.6$ and $15.25 \%$ compared with NM, RSM and WPFM. The highest value of weed biomass $\left(643.7 \mathrm{~g} \mathrm{~m}^{-2}\right)$ was obtained by using NM, while the lowest value was obtained by using BPFM.

As regard to the effect of mulching types on weed control efficiency, the values were $(40.91,30.35,5.2$ and zero\% for BPFM, WPFM, RSM and NM, respectively) that helped in maintaining higher moisture content in the crop root zone.

Table 7. The weed parameters under different treatments as an average in both seasons

\begin{tabular}{|c|c|c|c|c|}
\hline \multirow{2}{*}{ Treatment } & \multicolumn{2}{|c|}{ Weed number $\mathbf{m}-^{2}$} & \multirow{2}{*}{$\begin{array}{l}\text { Weed biomass } \\
\quad\left(\mathrm{g} \mathrm{m}^{-2}\right)\end{array}$} & \multirow{2}{*}{$\begin{array}{c}\text { Weed control } \\
\text { efficiency }(\text { WCE) }(\%)\end{array}$} \\
\hline & Broad-leaved & Grasses & & \\
\hline NM & 60.3 & 21.7 & 643.7 & 0 \\
\hline RSM & 57.3 & 18.3 & 610.0 & 5.2 \\
\hline WPFM & 48.7 & 17.3 & 448.3 & 30.35 \\
\hline BPFM & 41.3 & 16.3 & 380.3 & 40.91 \\
\hline
\end{tabular}

Table 8. The economic Evaluation of the present study

\begin{tabular}{ccccccc}
\hline \multirow{2}{*}{ Treatment } & \multicolumn{3}{c}{$\mathbf{1}^{\text {st }}$ season } & \multicolumn{3}{c}{$\mathbf{2}^{\text {nd }}$ season } \\
\cline { 2 - 6 } & $\begin{array}{c}\text { Total } \\
\text { production } \\
\text { costs, } \\
\text { L.E. ha }\end{array}$ & $\begin{array}{c}\text { Total } \\
\text { return, L.E. } \\
\text { ha }^{-1}\end{array}$ & $\begin{array}{c}\text { Net } \\
\text { return, } \\
\text { L.E. ha }\end{array}$ & $\begin{array}{c}\text { Total } \\
\text { production } \\
\text { costs, } \\
\text { L.E. } \text { ha }^{-1}\end{array}$ & $\begin{array}{c}\text { Total return, } \\
\text { L.E. ha }\end{array}$ & $\begin{array}{c}\text { Net return, } \\
\text { L.E. ha }\end{array}$ \\
\hline NM & 11783.9 & 21693.8 & 9909.8 & 11663.9 & 21528.0 & 9864.1 \\
RSM & 13909.5 & 25844.2 & 11934.6 & 13549.5 & 26288.8 & 12739.3 \\
WPFM & 15768.7 & 32700.8 & 16932.1 & 15168.7 & 32987.5 & 17818.8 \\
BPFM & 12079.9 & 37592.7 & 25512.8 & 11239.9 & 37961.1 & 26721.1 \\
\hline
\end{tabular}




\section{Economic Evaluation}

This study evaluated the effect of different types of mulching on some characteristics of the crop, irrigation and economic analysis of sugar beet. The data listed in Table 8 as economic analysis for two seasons indicated that treatment BPFM gave the best values of the net return and net profit followed by treatment WPFM then treatment NM which had the lowest value. Thus, the highest value of net return and total return under BPFM were treatments 25512.8 and 37592.7 in the first season, while in the second season were 26721.1 and 3761.1 LE $\mathrm{ha}^{\mathrm{A}-1}$. The lowest value of net return and total return under NM were treatments 9909.8 and 21693.8 in the first season, while in the second season were 9864.1 and 21528.0 LE/ha. The highest value of total production cost was obtained by using WPFM while the lowest value was obtained by using NM under in the first and second season.

\section{CONCLUSION}

Quality and beet yields were affected significantly by various mulching types. Both black and white polyethylene mulch positively affect sucrose, purity and extractable sugar percentage as well as root and sugar yield followed by rice straw mulch. Decreasing the amount of applied water and increasing beet yieldenhancing water use efficiency for both root and sugar yield. It can be recommended that plastic film mulch is preferentially applied for sugar beet production in newly reclaimed soils under semi-arid regions where scared irrigation water and high weed competition in sugar beet fields.

\section{REFERENCES}

A.O.A.C. 1980. Official Methods of Analysis, Association of Official Analytical Chemists, Washington, D.C. 376-384.

Afshar, R. K., C.Chen, J.Eckhoff and C. Flynn. 2018. Impact of a living mulch cover crop on sugarbeet establishment, root yield, and sucrose purity, Field Crop Research. 223: 150-154. https://doi.org/10.1016/j.fcr.2018.04.009

Artyszak, A., D.Gozdowski and K. Kucińska. 2014. The yield and technological quality of sugar beet roots cultivated in mulches, Plant Soil Environment. 60(10): 464-469. https://doi.org/10.17221/428/2014-PSE

Carruthers, A. and J. E. T.Oldfield. 1960. Methods for the assessment of beet quality, Technological Value of the Sugar Beet. 63( 1): 103-105.

Carruthers, A., J. E. T.Oldfield and H. J. Teague. 1962. Assessment of beet quality. Paper Presented to the ${ }^{15}$ th Annual Technical Conference, British Sugar Corporation LTD. 36.
Israelsen, O.W. and V.E. Hansen. 1962. Irrigation principles and practices $\left(3^{\text {rd }}\right.$ ed.), John Wiley and Sons Inc. New York.

Chen, Y., S. Chai, H. Tian, Y. Chai, Y. Li, L.Chang and H. Cheng. 2019. Straw strips mulch on furrows improves water use efficiency and yield of potato in a rainfed semiarid area, Agriculrural Water Management. 211:142-151. https://doi.org/10.1016/j.agwat.2018.09.048

CIMMYT. 1988. From Agronomic Data to Farmer Recommendations: An Economics Training Manual, Completely revised edition. Mexico. D.F.

DeBaets, S., J. Poesen, J. Meersmans and L. Serlet. 2011. Cover crops and their erosion-reducing effects during concentrated flow erosion," Catena. 85(3):237-244. https://doi.org/10.1016/j.catena.2011.01.009

Dregseth, R.J., M.A. Boetel, A.J. Schroeder, R.B. Carlson and J. S. Armstrong. 2003. Oat cover cropping and soil insecticides in an integrated sugar beet root maggot (Diptera: Otitidae) management program," J. of Economic $\begin{array}{llll}\text { entomology. } & 9 & (5): & 1426-1432 .\end{array}$ https://doi.org/10.1093/jee/96.5.1426

Gan, Y., K.H.M.Siddique, N.C.Turner, X.G. Li, J.Y.Niu, C.Yang, L.Liu and Q.Chai. 2013. Ridge furrow mulching systems- an innovative technique for boosting crop productivity in semiarid rain-fed environments, Advanced in Agronomy. 118: 429-476. https://doi.org/10.1016/B9780-12-405942-9.00007-4

Helaly, A.A., Y.A. Goda, A.S.El-Rehim, A.A.Mohamed and O.H. El-Zeiny. 2017. Effect of polyethelene mulching type on the growth, yield and fruits quality of Physalis pubescons, Advanced Plants Agricultuer Research. 6 (5): 1-7. 10.15406/apar.2017.06.00229

Jensen, M. G. 1983. Design and Operation of Farm Irrigation Systems, ASAE, Michign, USA. 82. https://doi.org/10.1016/0378-3774(82)90048-8

Kanani, E., H.Dehghanisanij and S. Akhavan. 2016. Effects of different irrigation methods and mulch on corn (zea mayz 1) evapotranspiration, yield, water use efficiency in a semiarid climate," $2^{\text {nd }}$ World Irrigation Forum (WIF2).11: 6-8. Chiang Mai, Thailand.

https://www.icid.org/wif2_full_papers/wif2_w.1.4.22.pdf

Li, S. X., Z. H.Wanga, S. Q. Li, Y. J.Gaoa and X. H. Tiana. 2013. Effect of plastic sheet mulch, wheat straw mulch and maize growth on water loss by evaporation in dryland areas of China, Agricultural Water Management. 116: 39 - 49. https://doi.org/10.1016/j.agwat.2012.10.004

Malik, A., A.S.Shakir, M.J.Khan, Naveedulah, M.Latif, M.Ajmal and S. Ahmad. 2018a. Effects of different mulching techniques on sugar beet performance under semi-arid subtropical climatic conditions, Pakistan J. of Botany. 50(3): 1219-1224.

Malik, A., A.S.Shakir, Naveedulah, M.J.Khan, M.Latif, M.S.Khattak and T.A. Khan. 2018b. Interactive effect of deficit irrigation and mulching on sugar beet production in Pakistan, Pakistan J. of Botany. 50( 5): 1775-1783. 
Mani, V.S., M.L.Malla and K.C.Gautam. 1973. Bhagwndas. Weed killing chemicals in potato cultivation, Indian Farming. VXXII. 17-18.

Mstat-c. 1989. "Users Guide: A Microcomputer Program for the Design, Management and Analysis of Agronomic Research Experiments," Michigan University, East Lansing, MC, USA. 17-18.

Mukherjee, A., M. Kundua and S.Sarkara. 2010. Role of irrigation and mulch on yield, evapotranspiration rate and water use pattern of tomato (Lycopersion esculentum L.)," Agricultural Water Management. 98(1):182-189. https://doi.org/10.1016/j.agwat.2010.08.018

Parmar,H. N., N. D.Polara and R. R. Viradiya. 2013. Effect of Mulching Material on Growth, Yield and Quality of Watermelon (Citrullus Lanatus Thunb) Cv. Kiran, Universal J. of Agricultural Research. ( 1) 2: 30 - 37. DOI: 10.13189/ujar.2013.010203

Patil, S.S., T.S.Kelkar and S.A. Bhalerao. 2013. Mulching: A Soil and Water Conservation Practice, Research J.of Agriculture and Forestry Sci. (1) 3: 26-29.

Petersen, J. and A. Rover. 2004. Comparison of sugar beet cropping systems with dead and living mulch using a glyphosate-resistant hybrid," J. of Agronomy and Crop Sci. .191(1): 55-63. https://doi.org/10.1111/j.1439037X.2004.00134.X

Renfield, E., A.Emmerich, G.Baumarten, C.Winner and U. Beiss. 1993. Zur voraussage des melosse suckers aus rubenanalyses," Zuker. In: 1st ed. In: Cock, D.A., Scott, R.K. (Eds.), The Sugar Beet Crop 27. Chapman \& Hall (World Crop Series), London, UK. 2-15 (1974).

Salman, A., A.S. R.Muhammad, F.S.Muhammad, S.Z.Syeda, H.K. Imran, A.Muhammad, S.Abdul Manan, I.Rashid and S. Muhammad. 2015. Mulching strategies for weeds control and water conservation in cotton, ARPN J. of Agricultural and Biological Sci. 10 (8): 299-306. http://www.arpnjournals.com/jabs/rese...

Sarkar, S. and S. R. Singh. 2007. Interactive effect of tillage depth and mulch on soil temperature, productivity and water use pattern of rainfed barley (Hordium vulgare L.), Soil Tillage Research. 92 (1-2): 79-86. https://doi.org/10.1016/j.still.2006.01.014

Sharma, R. and S.Bhardwaj. 2017. Effect of mulching on soil and water conservation $-A$ review.Agricultural Reviews. 38( 4): 311-315. 10.18805/ag.R-1732

Singh, G. and R. S. Jolly. 2008. Improving emergence of soybean (Glycine max) with straw mulch and other practices under normal and crusted soil conditions, Acta Agronomica Hungarica. 56( 3):275-283. https://doi.org/10.1556/AAgr.56.2008.3.3
Snedecor, G. A. and W. G. Cochran. 1976. Statistical Methods, Iowa State University Press, Amess.

Steel, R. G. and H. H. Torrie. 1980. Principles and Procedures of Statistics, second ed. Mc Grow Hill, New York.

Sturm, D.J., C. Kunz and R. Gerhards. 2016. Inhibtory effects of cover crop mulch on germination and growth of Stellaria media (L.) Vill., Chenopodium album L. and Matricaria chamomilla L. Crop Protection. 90: 125-131. 10.1016/j.cropro.2016.08.032

Teasdale, J.R. 1996. Contribution of cover crops to weed management in sustainable agricultural systems, J. of production agriculture. 9(4):475-479. https://doi.org/10.2134/jpa1996.0475.

Tegen, H., Y.Dessalegn and W.Mohammed. 2016. Influence of mulching and varieties on growth and yield of tomato under polyhouse, J. of Horticulture Forestry. 8 ( 1): 1-11. https://doi.org/10.5897/JHF2015.0395

Tunio, S. D., M. A.Ansari, H. R.Memon and M. R. Memon. 2007. Effect of different mulches and irrigation frequencies on growth and yield of sunflower," Pakistan J. of Agriculture, Agricultural Engineering and Veterinary Sci. 23( 1): 1-5.

Wu, I. P. and H. M. Gitlin. 1973. Hydraulics and uniformity for drip irrigation, $J$. of the Irrigation and Drainage Division. 99( 2): 157-168.

Xie, Z., Y.Wang and F. Li. 2005. Effect of plastic mulching on soil water use and spring wheat yield in arid region of Northwest China, Agricultural Water Management. 75( 1): 71-83. https://doi.org/10.1016/j.agwat.2004.12.014

Yamanaka, T., M.Inoue and I. Kaihotsu. 2004. Effects of gravel mulch on water vapor transfer above and below the soil surface. Agricultrual Water Management. 67(2):145155, https://doi.org/10.1016/j.agwat.2004.01.002

Yi, Z.X., W.X.Zhou, N.M.Tu, X.D. Tu, Y.L.Wu and W.L. Yang. 2007. Effects of no-tillage and straw mulching on soil nutrient content and drought resistance of maize on dry land, Research Agriculture Modern. 28(4): 490-493.

Yonts, C.D., J.A.Smith and R.G. Wilson. 2002. Evaluation of cover crop system for sugar beet production under furrow irrigation, J. of sugar beet research. 39(1/2): 25-36.

Zhang, Q.T., O.A.B. Ahmed, M.Inoue, M. C Saxena, K.Inosako and K. Kondo. 2009. Effects of mulching on evapotranspiration, yield and water use efficiency of Swiss chard (Beta vulgaris L. var. flavescens) irrigated with diluted seawater. J. of Food," Agriculture \& Environment. 7(4): 650-654. J-GLOBAL ID : 201302267671349360 


\section{الملخص العربي}

\section{الادارة المتكاملة للمياه والحشائش لمحصول بنجر السكر باستخدام نظم مختلفة لتغطية التربة فى المناطق المستصلحة حليثا}

محمد عنتر محمد مرسى، محمد سيد القاضى، لامى ممدوح محمد حامد، طلعت احمد ابراهيم، ايمان ابراهيم رفاعى عمارة

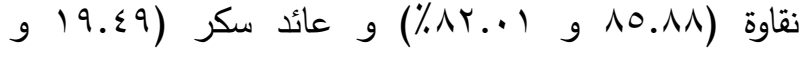

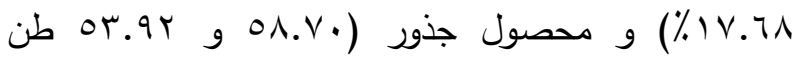

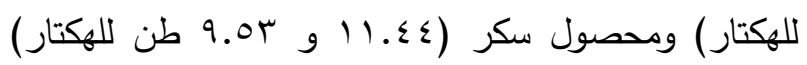

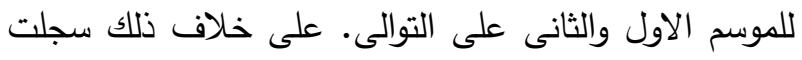
المعاملة كنترول (بدون تغطية NM) أعلى نسبة شوائب وأقل كفاءة مقاومة الحشائش. نتج متوسط كفاءة استخدام العياه

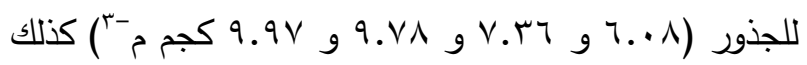

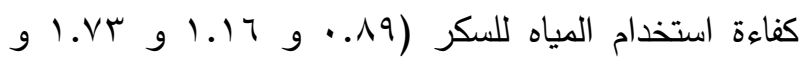

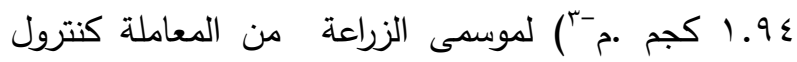
(بدون تغطية) و التغطية باستخدام قش الارز و استخدام فيلم بولى إثيلين الابيض و فيلم البولى إثيلين الاسود على التوالى.

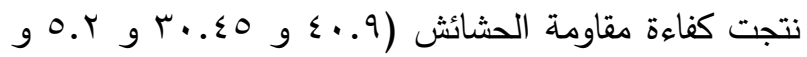
صغر) لكلا من المعاملة باستخدام فيلم البولى إثليلين الاسود

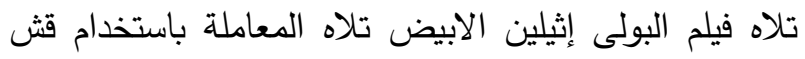
الارز تلاه المعاملة كنترول على التوالى مدا ساعد في الإنى الحفاظ على المحتوى الرطوبى فى منطقة الجذور .

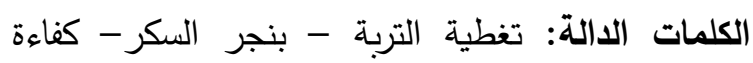

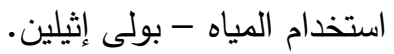

تلعب ادارة التقنيات الزراعية للتربة والمياه دورا مهما فى زيادة انتاجية المحاصيل. حيث تعد تغطية التربة من اهم الممارسات الزراعية للمحافظة على رطوبة التربة و مقاومة الحشائش وكذلك تحسين الخواص الفيزيائية للتربة. تمت اقامة تجربتين حقليتين بمحطة البحوث بوادى النطرون، معهر بحوث ادارة المياه, المركز القومى لابحاث

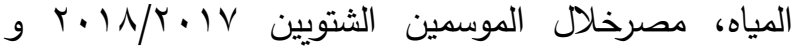

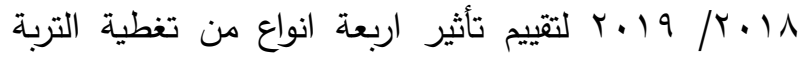
(بدون تغطية ككنترول (NM) و التغطية باستخدام قش الارز و التغطية باستخدام فيلم بولي إثيلين ابيض (RSM) و التغطية باستخدام فيلم البولى اثليلين الاسود Beta على محصول وجودة محصول بنجر السكر السين (BPFM) vulgaris

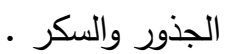

أظهرت النتائج فروق معنوية بين أنواع التغطية المختلفة. توالت أهم النتائج المتحصل عليها كالتالى حيث سجل كلا من التغطية باستخدام فيلم البولى إثيلين الاسود والابيض على لإلى

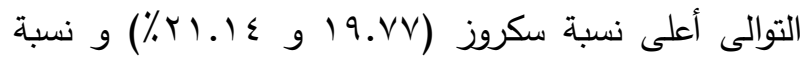

